Received: 27.01.2017.

UDK: 373.3.064.1

Reviewed paper

\title{
LEVEL OF COOPERATION DEVELOPMENT BETWEEN FAMILY AND SCHOOL IN ELEMENTARY SCHOOLS
}

\author{
Nusreta Omerdić \\ Faculty of Education, University in Travnik \\ nusi.o@hotmail.com \\ Mediha Riđić \\ Faculty of Education, University in Travnik \\ mediha.ridjic@hotmail.com
}

\begin{abstract}
One of the important features of effective pedagogical school is developed cooperation with parents. Cooperation represents a joint action and negotiation, which is aimed at finding solutions, and a new, common ground. Cooperation between schools and families, may be traditional and partnership oriented. In what way it will be achieved and placed, depends on the legal regulations, school environment, individual characteristics of teachers, socio-demographic and psychosocial characteristics of the parents.

The aim of this study is to determine the level of development of cooperation between the family and school, whether the cooperation is still traditional or has established partnerships between families and schools. The paper is based on the assumption that parents do not participate in decision-making at the school and that the cooperation between family and school in primary schools is still traditional.

The results showed that parents are not involved in decision-making at the school, that the cooperation between family and school is still traditional and that is mainly related to parent meetings and informative conversations, without involvement of the partnership.
\end{abstract}

Keywords: family, school, cooperation, communication, partnership. 


\section{INTRODUCTION}

The formation of personality is a complex process of cultivation, or the development of certain fundamental human skills, achieved by transferring the basic cultural heritage on the child from early learning and communication with other family members, to training for self-activity and participation in the creative process of cultural development; through socialization as a process by which a child is introduced to the rules of social life and behavior of their society; and individualization as a process by which he develops internal motivation system in accordance with the personal characteristics of his personality (Ćatić, 2005). The most important role in the social environment has a family, and the school, as a secondary educational factor. Holders of the educational role of the family are the parents. Although the role of the mother and father have their own specifics, the role of both parents are equally important for education in the upbringing of the child. So, families are primary, they are "educators of human nature because direct interaction takes place through them and children acquire their foundational learning experience" (Golubović, 1981, 43).

At school, the fundamental role of education has a teacher in lower primary school grades, and the class teacher in the upper grades as well as in high school. For the healthy and smooth development of personality, the existence of optimal conditions is required in family and school, both material as well as social. A student at the school spends a lot of time exposed to the constant intellectual efforts, which holds that schools educate more and families raise more, although training and education are integrated processes. But even in the period of education, the child is much longer under the aegis of the home than school. Therefore, schools and families need to perform a unique impact on the students. The full understanding and practical realization of the basic goals of education largely depends on expertly organized and pedagogically clear focused cooperation between families and schools. The initiative and the focus of activities in this cooperation belongs to teachers, class teachers, professional associates (pedagogues and psychologists) and school principals. Cooperation makes it possible to always know what and how the student works, when he and why he needs the assistance and how far the results of his work reach. That is how the cause of failure in certain subjects becomes eliminated, the appearance of potential bad behavior undermined, and deviations in behavior corrected. According to Ćatić (2005) developed forms of cooperation with educational institutions (parentteacher meetings, lectures, school for parents, discussions, visiting family, individual and group consultations) are in a great number of our schools, only partially in function and reduced mainly to the simplest communication of parents and educators, unfortunatelly. This communication is often one-way and simplified and does not use all the possibilities in the contact between a parent and school. Parents do not have the necessary education of elementary educational processes in collaboration with educational institutions, while a large number of teachers and management of educational institutions, tolerate ignorance which often leads to a break-off with each other. Šimleša (1978) points out that the sense of cooperation should be mutual assistance and harmonization of educational goals. The school, which is a professional pedagogical body, should familiarize parents 
with the educational goals and educational tasks of schools as well as methods of family upbringing. Cooperation with parents schools should use to meet the economic, social and cultural opportunities the environment in which the student lives. Regardless of the organizational form of cooperation between the school and the family, they must support each other, but also respect those educational functions that are specific to each of these educational institutions. Parents today realize the importance of assistance to be provided to their children, and educational institutions are obliged to help them in education. "The parents understand the importance of assistance to be provided to their children. However, despite this, some help is not provided because of workload or the lack of necessary knowledge (education)" (Stevanović, 2000, 404).

Catić (2005) points out that the cooperation of the school with the family must be programmed each school year. The schools should organize school for parents, which in many countries has shown good results. Neither the parents are no longer satisfied with mere formalistic reports on evaluations of their children. They want to learn how to help their children in certain subjects, they want to hear more about educational methods that they can apply in the family. Research shows unequal relationship of parents towards school. For the success of children more interested parents are those with higher education and those with three or four children. The most excellent students are just from these families. In addition, most children show better results in complete and less of deficient families (Stevanović, 2000).

Because of the importance of cooperation between family and school, the problem of research relates to the question: Do families and schools invest sufficient efforts to establish quality cooperation? Therefore, the aim of this study was to determine the level of development of cooperation between the family and school, whether the cooperation still traditional or have established partnerships between families and schools.

\section{RESEARCH METHODS}

The study used analytical and descriptive method and content analysis methods. Basic search was conducted over Google Scholar, Web of Science, ResearchGate, Hrčak (Portal of scientific newspapers of Croatia Republic). Articles published in print magazines are also reviewed: „Didaktički putokazi“, “Život i škola”, „Napredak“, „Sociologija i prostor", and accessible collections of papers from scientific conferences. Database search was conducted in October 2015 and was based on the content analysis summaries of publications containing the following keywords: school, cooperation, children, parents, students, teachers, family, partnership, communication, education reform, transition , forms of cooperation between educators and parents, urban and rural areas, the traditional approach, partnership approach, children's rights, development of democracy, competence, academic achievement. The considered works have been published in Bosnian, Croatian and Serbian language. In analyzing the contents are included the articles that were published in the period from 2002 to 2015, related to the cooperation of family and school, education reform, building partnerships, communication between 
family and school, whose respondents were parents, teachers / lecturers, school directors and pedagogues.

\section{RESEARCH RESULTS}

Table 1. Sistematic research overview

\begin{tabular}{|c|c|c|}
\hline $\begin{array}{c}\text { Author \& } \\
\text { year }\end{array}$ & Topic & Research results \\
\hline $\begin{array}{l}\text { Itković, } \\
\text { Z.Boras, } \\
\text { S.(2002) }\end{array}$ & $\begin{array}{l}\text { Cooperative } \\
\text { communication } \\
\text { between teacher \& } \\
\text { parent } \\
\text { Parents as partners } \\
\quad \text { in school }\end{array}$ & $\begin{array}{l}\text { - Democratize school and social relationships; } \\
\text { - Joint dialogue of parents, teachers and students } \\
\text { in problemsolving; } \\
\text { - It is important to express your opinions, but } \\
\text { also respect other people's opinion. }\end{array}$ \\
\hline $\begin{array}{c}\text { Ajanović, Dž. } \\
\text { (2006) }\end{array}$ & $\begin{array}{l}\text { Significance of } \\
\text { communication for } \\
\text { professionalism in } \\
\quad \text { education }\end{array}$ & $\begin{array}{l}\text { - Developing communication skills and ability } \\
\text { as an essential prerequisite for professional } \\
\text { development of teachers and other professionals } \\
\text { who deal with education andupbringing; } \\
\text { - Professional competence of teachers. }\end{array}$ \\
\hline $\begin{array}{c}\text { Marušić, I. } \\
\text { Ristić Dedić, } \\
\text { Z. } \\
\text { Pavin Ivanec, } \\
\text { T. } \\
\text { Jurko, L. } \\
\text { (2006) }\end{array}$ & $\begin{array}{l}\text { Parent-school } \\
\text { cooperation; Views } \\
\text { of parent and } \\
\text { teacher }\end{array}$ & $\begin{array}{l}\text { - Teachers and parents of the traditional forms } \\
\text { of cooperation (departures on information } \\
\text { appointments and parent-teacher meetings) } \\
\text { estimated useful for the progress of children in } \\
\text { school; } \\
\text { - Parents do not participate in decision-making } \\
\text { at the school; } \\
\text { - The opening of the school to the parents } \\
\text { and learning about the various possibilities of } \\
\text { participation. }\end{array}$ \\
\hline $\begin{array}{c}\text { Jurić, V. } \\
\text { Maleš, D. } \\
(2008)\end{array}$ & School \& parents & $\begin{array}{l}\text { - There is an abiding interest in relationship } \\
\text { between schoolandfamily; } \\
\text { - The mutually complementary objectives, } \\
\text { convergence of interests and mutual } \\
\text { understanding. }\end{array}$ \\
\hline
\end{tabular}




\begin{tabular}{|c|c|c|}
\hline $\begin{array}{l}\text { Polovina, N. } \\
\text { (2008) }\end{array}$ & $\begin{array}{c}\text { The contribution of } \\
\text { school to building } \\
\text { partnership with } \\
\text { parents }\end{array}$ & $\begin{array}{l}\text { - The construction of the cooperation program } \\
\text { must be preceded by a process of systemic } \\
\text { and systematic shaping of the topic at the level } \\
\text { of every individual school for the purpose of } \\
\text { cleared existing multiverse meanings which } \\
\text { provide the basis for clear, locally meaningful } \\
\text { and sustainable cooperation programs. }\end{array}$ \\
\hline $\begin{array}{l}\text { Nikčević- } \\
\text { Milković, A. } \\
\text { (2008) }\end{array}$ & $\begin{array}{l}\text { Project „School } \\
\text { opened to } \\
\text { parents“ aiming at } \\
\text { developing school- } \\
\text { parent partnership } \\
\text { as prerequisites } \\
\text { for sustainable } \\
\text { development }\end{array}$ & $\begin{array}{l}\text { - Partnership between schools and parents in } \\
\text { Croatian schools poorly developed and very } \\
\text { difficult to develop; } \\
\text { - Necessary active involvement of both sides } \\
\text { through concrete action and the development of } \\
\text { competencies to initiate further action. }\end{array}$ \\
\hline $\begin{array}{l}\text { Kosić, A. } \\
(2009)\end{array}$ & $\begin{array}{l}\text { Parents \& teachers } \\
\text {-partners in } \\
\text { improving of } \\
\text { educational process } \\
\text { in primary school. }\end{array}$ & $\begin{array}{l}\text { Better communication with parents; } \\
\text { - Involving parents in the program and the } \\
\text { school curriculum; } \\
\text { - The openness of the entire school community } \\
\text { to encourage partnerships between parents, } \\
\text { teachers and other school staff; } \\
\text { - Pedagogical education and training, as parents } \\
\text { and teachers; } \\
\text { - Efforts of the wider community to create } \\
\text { conditions that will encourage and enhance } \\
\text { partnerships }\end{array}$ \\
\hline $\begin{array}{c}\text { Pavlović, S. } \\
\text { (2009) }\end{array}$ & $\begin{array}{l}\text { Reform of } \\
\text { (elementary) } \\
\text { education - at the } \\
\text { intersection of real } \\
\text { and imaginary }\end{array}$ & $\begin{array}{l}\text { - The negative attitude of teachers and parents } \\
\text { to the reform of elementary school, which stems } \\
\text { from the lack of information, lack of cooperation } \\
\text { between the relevant parties, lack of preparation } \\
\text { and school teachers for the implementation of } \\
\text { reforms and the like. } \\
\text { - All relevant stakeholders should work } \\
\text { synergistically to ensure correct and efficient } \\
\text { implementation of the education reform, taking } \\
\text { into account the welfare of children and the } \\
\text { future of society. }\end{array}$ \\
\hline
\end{tabular}




\begin{tabular}{|c|c|c|}
\hline $\begin{array}{c}\text { Pahić, T; } \\
\text { Miljević- } \\
\text { Riđički, R. } \\
\text { Vizek } \\
\text { Vidović, V. } \\
\text { (2010) }\end{array}$ & $\begin{array}{c}\text { Involvement of } \\
\text { parents in school } \\
\text { life: } \\
\text { The perception } \\
\text { of the general } \\
\text { population of } \\
\text { parents and parent } \\
\text { representatives in } \\
\text { school bodies }\end{array}$ & $\begin{array}{l}\text { - The relationship between schools and parents } \\
\text { in Croatia is mostly traditional; } \\
\text { - Communication with parents rare and focused } \\
\text { on individual problems and is mostly initiated by } \\
\text { schools. }\end{array}$ \\
\hline $\begin{array}{c}\text { Lukaš, M. } \\
\text { Gazibara, S. } \\
\text { (2010) }\end{array}$ & $\begin{array}{l}\text { Modalities of } \\
\text { cooperative } \\
\text { relations between } \\
\text { school pedagogue } \\
\text { and parents }\end{array}$ & $\begin{array}{l}\text { - Most parents do not know whether the } \\
\text { school offered some form of cooperation with } \\
\text { educators; } \\
\text { - Most parents do not cooperate with teachers } \\
\text { (there was no opportunity or need for } \\
\text { cooperation); } \\
\text { - The need for active involvement of parents in } \\
\text { school life. }\end{array}$ \\
\hline $\begin{array}{c}\text { Meholjić, A. } \\
\text { (2011) }\end{array}$ & $\begin{array}{c}\text { The need for } \\
\text { family-school } \\
\text { cooperation }\end{array}$ & $\begin{array}{l}\text { - Priority of schools - successful and continuous } \\
\text { cooperation with the parents; } \\
\text { - Finding different ways of communication to } \\
\text { suit the needs of different families. }\end{array}$ \\
\hline $\begin{array}{c}\text { Pahić, T; } \\
\text { Miljević- } \\
\text { Riđički, R. } \\
\text { Vizek } \\
\text { Vidović, V. } \\
\text { (2011) }\end{array}$ & $\begin{array}{l}\text { Parent - school } \\
\text { cooperation } \\
\text { in Croatia: } \\
\text { resemblances \& } \\
\text { differences between } \\
\text { urban \& rural } \\
\text { areas }\end{array}$ & $\begin{array}{l}\text { - The traditional approach of cooperation } \\
\text { between parents and schools; } \\
\text { - According to Parents a significant obstacle } \\
\text { to cooperation refers to personal lack of time, } \\
\text { especially according to parents from urban areas; } \\
\text { - The stronger association of parents and schools } \\
\text { in rural areas; } \\
\text { - Greater satisfaction with communication and } \\
\text { the influence of the school with their parents in } \\
\text { rural areas. }\end{array}$ \\
\hline $\begin{array}{c}\text { Zuković, S. } \\
\text { (2012) }\end{array}$ & $\begin{array}{l}\text { Relationship } \\
\text { between family } \\
\text { \& school: From } \\
\text { cooperation to } \\
\text { partnership }\end{array}$ & $\begin{array}{l}\text { - Assigning to parents an equal status in the } \\
\text { implementation of key activities and decision- } \\
\text { making with regard to education of their } \\
\text { children; } \\
\text { - Involve parents in the learning process; } \\
\text { - Support local communities to strengthen the } \\
\text { partnership between the family and school. }\end{array}$ \\
\hline
\end{tabular}




\begin{tabular}{|c|c|l|}
\hline $\begin{array}{c}\text { Pavlović } \\
\text { Breneselović, } \\
\text { D. } \\
\text { (2013) }\end{array}$ & $\begin{array}{c}\text { The partnership } \\
\text { of the family } \\
\text { and school as } \\
\text { a dimension of } \\
\text { quality education } \\
\text { Controversy of } \\
\text { participation of } \\
\text { parents in decision- } \\
\text { making at school }\end{array}$ & $\begin{array}{l}\text { - The fundamental problem in establishing a } \\
\text { partnership of family and school: the inequality } \\
\text { in power and diversity of social roles that } \\
\text { comes from a diversity of perspectives and } \\
\text { phenomenological diversity; } \\
\text { - Alternative - participation of parents in the } \\
\text { school. }\end{array}$ \\
\hline $\begin{array}{c}\text { Popović,D. } \\
\text { (2104) }\end{array}$ & $\begin{array}{c}\text { Partnership } \\
\text { between families } \\
\text { and schools } \\
\text { in transition } \\
\text { conditions }\end{array}$ & $\begin{array}{l}\text { - In terms of the transition the joint action of the } \\
\text { family and school is required on the principle of } \\
\text { partnership; } \\
\text { - The opening of schools for parental } \\
\text { involvement in school activities that could } \\
\text { contribute to laying the foundation for } \\
\text { substantial cooperation. }\end{array}$ \\
\hline $\begin{array}{c}\text { Skutor, M. } \\
\text { (2014) }\end{array}$ & $\begin{array}{c}\text { Family } \text { - school } \\
\text { partnership - the } \\
\text { foundation for } \\
\text { children success }\end{array}$ & $\begin{array}{l}\text { - Motivation of parents for involvement in the } \\
\text { education of their children; } \\
\text { - Teacher competencies necessary for teaching; } \\
\text { - Partnership orientation of parents, instead of } \\
\text { the traditional. }\end{array}$ \\
\hline
\end{tabular}

\section{DISCUSSION}

Longo (2005) points out that the parents are of one of the most valuable and least regarded school resources. In the process of education, schools and families have to rely on each other, the mutual cooperation and assistance. "School must be understood as a community of teachers, students and parents. Where this is lacking, there is no full realization of educational roles. It is necessary that all three of the components are involved in education" (Bošnjak, 1999, str. 70).

Every activity in school, every problem, every question, every goal of any activity implies the presence of the family. Indirectly, through the characteristics or behavior of the child, either directly, through a concrete commitment of the family. Family - school cooperation contributes to the qualitative strengthening of both sides. It helps family to strengthen their educational abilities and convince it of the value of its contribution, and on the other hand, strengthens the professional qualifications of the school and its teachers for successful educational work, not only with students but also with their parents. From the efforts of both sides to cooperate better, the positive effects will come up that will mostly benefit the learner. Today, everybody is talking about the partnership between teachers and parents. Partner relationships of teachers and parents means a child 
in the center of each of their activities. Partners have the same interests, the same goals and the need to implement the same tasks to them to approach jointly defined goals. The partnership aims to achieve primarily those goals which are in the interest of the child, that child can reach - based on complete openness and honesty on both sides and hence the partnership between the parents, the family and the school gave much more valuable results than cooperation ever could. Pašalić-Kreso (2004) points out that the authors who have written about the values and benefits of the partnership family and school, base their claims on a number of studies (eg: Davies, 1998; Epstein, 1994, 1995, 1996; Loucks 1992; Warner 1991) which confirm that the chances of a child for success in school significantly increase if schools and families work together. But this is not enough if the school and the family, before everything, do not build mutual respect and appreciation.

Table 2. Difference between family-school cooperation and partnership (Pašalić-Kreso, 2004, 343).

\begin{tabular}{|l|l|}
\hline \multicolumn{1}{|c|}{ Family-school cooperation } & \multicolumn{1}{c|}{ Family-school partnership } \\
\hline $\begin{array}{l}\text { Parents are not involved in all school } \\
\text { activities. }\end{array}$ & $\begin{array}{l}\text { Parents are the first teachers of their } \\
\text { children and they are partners of school. }\end{array}$ \\
\hline $\begin{array}{l}\text { Communication with parents is rare } \\
\text { and becomes more common only when } \\
\text { problems occur. }\end{array}$ & $\begin{array}{l}\text { Communication with parents starts from } \\
\text { the beginning of the school year and } \\
\text { takes place through joint work, planning } \\
\text { and setting goals for each student. }\end{array}$ \\
\hline $\begin{array}{l}\text { Parents may visit the school only in the } \\
\text { exact defined days. }\end{array}$ & Parents are welcome at any time. \\
\hline $\begin{array}{l}\text { Involving parents in school work comes } \\
\text { down to irregular help with homework } \\
\text { and interest for school grades. }\end{array}$ & $\begin{array}{l}\text { Parents are a valuable resource to fill in } \\
\text { school learning. }\end{array}$ \\
\hline $\begin{array}{l}\text { Local communities and schools should } \\
\text { operate separately, ie, "all at their place" }\end{array}$ & $\begin{array}{l}\text { The school belongs to the local } \\
\text { community, which is an important source } \\
\text { of knowledge for students in preparation } \\
\text { for real life. }\end{array}$ \\
\hline
\end{tabular}

Partnership between schools and families assumes that schools and families must be equal partners and if not, they must become it, at least at the level of respect for the dignity of each. In this process, school is taking the first steps. It is preparing a program to raise pedagogical culture of parents, it opens the door for parents around the school, it understands the problems and difficulties through which the families pass, it respects the family of his students, it develops a relationship of mutual trust and create an atmosphere of honesty and openness (Pašalić-Kreso, 2004; by Berger, 2000). Surveys carried out the 80 s in the US, Canada and Western European countries have shown that building a partnership between parents and the school gives good results especially in children 
who have difficulties in monitoring and mastering schoolwork, which have certain social or emotional problems, who have certain health problems, which fall into the category of children with special needs (gifted children or those lagging behind in development), and from a minority group (ethnic, religious, linguistic).

For the school, families and parents are transmitters of cultural, traditional, and normal value, not just parents of students. School should enable the exchange of the most important educational inter-parent experiences, (what, when and why, applied through a specific educational process), and explain how to act towards a child in certain situations.

Pašalić-Kreso (2004) further states that if the school and the community unite their forces in a joint effort to help the family, the child will also be provided with incredibly good effects. On several occasions, both parents and teachers confirmed that such help is needed. School should be open longer than its normal working hours and working days, in order to provide an opportunity of gathering and parents and students in their area.

\section{CONCLUSION}

This study analyzed the works of authors from Bosnia and Herzegovina, Croatia and Serbia, and the results showed that the cooperation between family and school in primary schools is still traditional. Parents are not involved in the decision-making process at the school. Communication with parents is rare and focused on individual problems and is mostly initiated by schools. This paper attempted to point out the importance of establishing good cooperation and partnership between family and school. It can be concluded that this requires two active parties involved. Both, schools and parents need to be actively involved in this process and encourage each other to engagement. So, on the basis of the results obtained, we conclude that if we want to develop and nurture partnerships of family and school, we have to involve parents more in school life, to involve them in decision-making concerning their child, respect their opinions about the child. The school should devise ways in which it could attract parents and actively involve them in the life of the school. School, teachers and parents should give more contribution in the joint action, and that does not involve just words on paper, but it really requires practice, working on building and fostering partnerships. If parents and teachers develop partnerships arising from the above assumptions, it will certainly be the way to faster and easier access to quality changes. Therefore, the future school process is based on humane democratic values where teachers, students and parents are equal partners. Each school should proceed from their possibilities, of the possibilities of development of their social environment, but at the same time think of the wide range of educational, cultural, social, religious, professional, and economic levels and parents, families of their students. The future education will not be successful nor qualitative without construction and development partnerships of family and school, with the emphasis on child. 


\section{REFERENCES}

1. Ajanović, Dž. (2006). Značaj komunikacije za profesionalizam u obrazovanju. Source: Proceedings of the Islamic Pedagogical Faculty in Zenica, 04: pages:149-162, on www.ceeol.com očitano: 25.10.2105.

2. Bošnjak, H. (1999). Psihološko-pedagoške postavke odgoja i obrazovanja. Tešanj: Planjax.

3. Breneselović, D. (2013). Partnerstvo porodice i škole kao dimenzija kvaliteta obrazovanja: Kontroverze učešća roditelja u odlučivanju, Proceedings of the Institute for Pedagogy \& Andragogy, Beograd.

4. Ćatić, R. (2005). Osnovi porodične pedagogije. Zenica: Faculty of Pedagogy.

5. Golubović, Z. (1981). Porodica kao ljudska zajednica, Zagreb: Naprijed.

6. Itković, Z. I Boras, S. (2002). Kooperativna komunikacija između nastavnika i roditelja: Roditelji partneri školi, Proceedings to Quality school, elementary school, day 2, Split-Dalmatia County, Split.

7. Jurić, V. i Maleš, D. (2008). Škola i roditelji, Napredak: Magazine for Pedagogical theory and practice (1330-0059), 135 (2) 133-140, Zagreb.

8. Kosić, A (2009). Roditelji i nastavnici - partneri u unapređivanju odgojno-obrazovnog procesa u osnovnoj školi, Život i škola, 22 (2): 227-234.

9. Longo, I (2005). Škola kao mjesto edukacije roditelja za kvalitetno roditeljstvo (Roditelji i učitelji na putu prema kvalitetnoj školi). Proceedings of Expert Scientific Conference with International cooperation - 4 days Split-Dalmatia County (pp. 130136). Split.

10. Lukaš, M. I Gazibara S. (2010). Modaliteti suradničkih odnosa školskog pedagoga i roditelja. Život i škola, 56 (24): 210-229.

11. Marušić, I., Ristić Dedić, Z., Pavin Ivanec, T. i Jurko, L. (2006). Roditeljska suradnja sa školom: Pogledi rodittelja i učitelja, available at: http://bib.irb.hr/prikazirad?lang=en\&rad=588656 očitano: 18.10.2015.

12. Meholjić, A. (2011). Potreba saradnje obitelji sa školom, available at: http:// www.ringeraja.ba/clanak/potreba-saradnje-obitelji-sa-skolom_640.html?page=3, 18.10.2015.

13. Nikčević-Milković, A. (2008). Projekt „Škola otvorena roditeljima“ u cilju ostvarenja partnerstva škole i roditelja kao pretpostavke održivog razvoja, available at: http:// bib.irb.hr/datoteka/655267.rad_OR.pdf. 25.10. 2015.

14. Pahić, T., Miljević-Riđički, R. i Vizek Vidović, V. (2010). Uključenost roditelja u život škole: Percepcija roditelja opće populacije i predstavnika roditelja u školskim tijelima. Odgojne znanosti, 12(2): 329-346.

15. Pahić, T., Miljević-Riđički, R. i Vizek Vidović, V. (2011). Suradnja roditelja i škole u Hrvatskoj: sličnosti i razlike urbanih i ruralnih sredina. Sociologija i prostor, 49 (2): 165-184.

16. Pašalić-Kreso, A. (2004). Koordinate obiteljskog odgoja. Sarajevo: Jež.

17. Pavlović, S. (2009). Reforma (osnovnoga) obrazovanja - na raskrižju stvarnoga i zamišljenoga, Contemporary issues, issue: 8/2009, pages:47-62, on www.ceeol.com 
25.10. 2015.

18. Polovina, N. (2008). Doprinosi škole građenju partnerstva sa roditeljima. Insitute for Educational Research. UDK 37.064.1, Beograd.

19. Popović, D. i Zuković, S. (2014). Partnerstvo porodice i škole u uslovima tranzicije. Proceedings of Faculty of Philosophy in Pristina, 2014., No.44-1: 219-235, Priština

20. Skutor, M. (2014). Partnerstvo škole i obitelji - temelj dječjeg uspjeha. Napredak: Magazine for pedagogical theory and practice, 154 (3): 209-222.

21. Stevanović, M. (2000). Obiteljska pedagogija. Varaždinske Toplice.

22. Šimleša, P. (1978). Pedagogija, Zagreb: Pedagogic-Literary Assembly.

23. Zuković, S. (2012). Odnos između porodice i škole: Od saradnje ka partnerstvu, Proceeding/book 2. Novi Sad: Faculty of Philosophy, Novi Sad University. 